\title{
Creativity. A biological weapon?
}

\author{
Paulo Tiago Cabeça \\ tgcabeca@uevora.pt
}

Keywords: Creativity, Conscious, Subconscious, Art, Animal Creativity, Cerebellum.

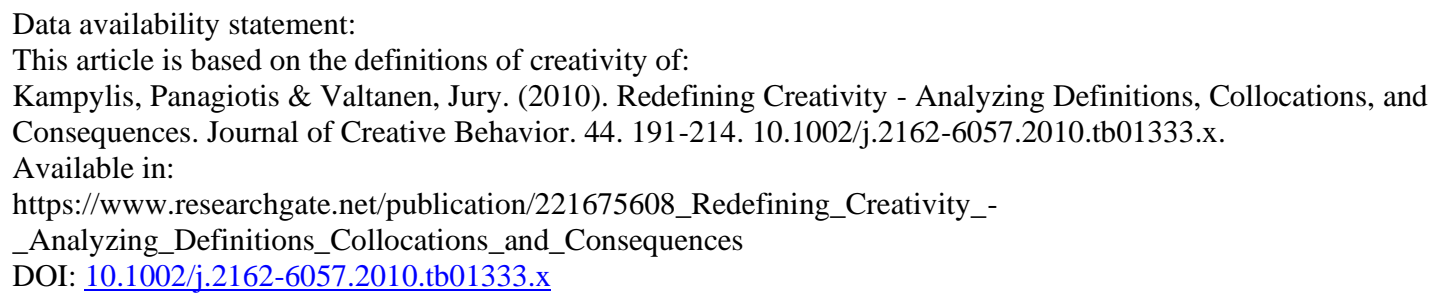

\begin{abstract}
We continue in this text the investigation that takes place in Cabeça Paulo (2021) ${ }^{1}$. It is intended in this work to analyze the various definitions that exist for the phenomenon of creativity and to contribute to a reflection on the theme of its definition. Considering that although studied in various areas, from art, to history, from psychology to psychiatry, from zoology to philosophy, from mathematics to neurology, among others, creativity continues today without a concrete definition stripped of ambiguities. Could it be a genetic tool naturally common to many living things? Common to many animal species, which allows them to interact and thrive in the environment, is creativity a biological phenomenon? Is Art, eventually as a manifestation of the subconscious, a consequence of it?
\end{abstract}

Kampylis and Valtanen (2010) in their work on the possibility and need for ethical creativity, begin research precisely on the concept or concepts of creativity and its meanings. Although this study was expanded and deepened in 2019 by Puryear J. \& Lamb Kristen. (2019) Kamplylis \& Valtanen state that what constitutes creativity has not yet been defined or presented in a clear and unequivocal way. Semantics arise from multiple ways from multiple contexts in which the term has been used and evoked throughout history. In addition, the nature and definition of creativity, such as that of intelligence, vary between cultures. They argue that there are currently forty-two (42) definitions and one hundred and twenty (120) colocations for what they describe as the "complex phenomenon of human creativity", conclusions of the most varied authors and researchers. The noun creativity, and definition of creativity vary across cultures (Starko, 2005), according to Kampylis and Valtanen, is not a recent and fashionable

\footnotetext{
${ }^{1}$ Cabeça, P.T. (2021). The Venus of our anxiety. The first art was visceral. Academia Letters, Article 454. https://doi.org/10.20935/AL454.
} 
term, it is something that has accompanied us for decades and can also be somewhat confusing and sometimes misunderstanding. It first appeared in print in 1875. It derives from the Latin creatus, past participle of creare, which means "to make, to produce" and is related to crescere (= arise, to grow). So right at the root of the word we find a possible definition. Creativity can thus be something concrete and not abstract because it is done or produced and will be something that does not replicate what existed before, because something that grows or arises will always be superlative to something that just mimics. The authors also mention that according to Piirto (2004), creativity as a scientific term has its root in psychology, (Creativity, 2009) more specifically referenced in Guilford's article (Guilford, 1950) addressed to American Psychologist and Stein's (1953) famous article in the Journal of Psychology. Runko \& Jaeger transcribe this definition (Stein, 1953):

\begin{abstract}
Let us start with a definition. The creative work is a novel work that is accepted as tenable or useful or satisfying by a group in some point in time . . . By "novel" I mean that the creative product did not exist previously in precisely the same form .... The extent to which a work is novel depends on the extent to which it deviates from the traditional or the status quo. This may well depend on the nature of the problem that is attacked, the fund of knowledge or experience that exists in the field at the time, and the characteristics of the individual creative and those of the individuals with whom he [or she] is communicating. Often, in studying creativity, we tend to restrict ourselves to a study of the genius because the "distance" between what he [or she] has done and what has existed is quite marked ... In speaking of creativity, therefore, it is necessary to distinguish between internal and external frames of reference. (pp. 311-312)
\end{abstract}

Therefore according to Stein for something to be considered creative it would have to be considered by others as new and useful. This definition will already be something different from that reached by the Latin root of the word which described something that arises - which in fact may be similar to the new one mentioned above - but now also described as useful, when it was sufficient before that it was concrete.

The authors point out that their research focuses only on the sumula of conclusions and studies available in English. They speak of three eras of development of the concept of creativity. The metaphysical era, which extends from antiquity to the Renaissance, where some geniuses were considered capable of creating from nothing ("ex nihilo") and through the divine or other kind of inspiration. The aristocratic era that went from the Renaissance to the mid-20th century, where some charismatic geniuses were able to create from something. The democratic era, from the mid-20th century to the day of today, where anyone is considered capable of creating from anything. This includes Sternberg and Lubart's investment theory, refered to by Cabeça (2020) on his theses "Creativity as a process of the conscious and subconscious in Art. Barrística (art in clay) as a case study" - among others. Kampylis and Valtanen, considering the ethical, multidimensional, and holistic approach to their investigation, state that there is a need to move to a fourth era. That of conscious creativity. In this, all experienced, conscious, and wise human beings are considered capable of creating something ethical and constructive for all mankind, guided by the notion and awareness of good and evil. Thus the focus should be radically more pointed in the direction of constructive and benevolent creativity (for example the discovery of penicillin) and less on activities that promote malevolent and destructive creative activities (e.g. the invention of the atomic bomb). However from here we can retain as interesting data this that creativity advantageous to some can be considered destructive creativity for others. It will perhaps depend on the context or environment. For example: the weapon invented to hunt animals and thus allow the survival of a human being today, can be used in war to take 
the life of his fellow man tomorrow. And today's animal hunter could be the killer of men tomorrow. It depends only on changing the context or situation. In a way, creativity, one might say, also mirrors the complex nature of humans.

Kampylis and Valtanen claim that many researchers have produced a wide range and number of definitions for creativity and that this is in fact a real problem and a major challenge for research. In particular, the notion of metonymy. Where one takes the whole for the part, can prejudice and, according to the authors, conditionate the cognitive process itself. This may result in narrower conceptions and conceptualizations for the definition of creativity. This can help to form the perception that creativity is not as comprehensive as it really will be, they say. Kaufman and Sternberg (2006) give an example that creativity is difficult to study. They tell the story of the man who lost his keys in the street at night and searches them under the diffuse light of a lamp. A policeman comes to help him and asks, are you sure you lost them here? To which the man replies: No. I lost them over there. But here I have the light from the lamp! Many scientists prefer easier problems, Kaufman and Sternberg say, because creativity is also difficult to measure and determine. Kampylis and Valtanen systematized many of these definitions to obtain points of agreement. Generating the following Table 1 (Kampylis \& Valtanen, 2010, p.199-203) with these definitions:

Table 1. Forty-two definitions of creativity (Kampylis \& Valtanen, 2010, p.199-203)

\begin{tabular}{|c|c|c|}
\hline Author(s) & Year & Definition \\
\hline Guilford & 1950 & $\begin{array}{l}\text { ". . refers to the abilities that } \\
\text { are most characteristic of } \\
\text { creative people. Creative } \\
\text { abilities determine whether } \\
\text { the individual has the power } \\
\text { to exhibit creative behavior } \\
\text { to a noteworthy degree." (p. } \\
444) .\end{array}$ \\
\hline Stein & 1953 & $\begin{array}{l}\text { "... that process which } \\
\text { results in a novel work that is } \\
\text { accepted as tenable or useful } \\
\text { or satisfying by a group at } \\
\text { some point in time". (p. } 311) \text {. }\end{array}$ \\
\hline Rogers & 1954 & $\begin{array}{l}\text { "... is the emergence in } \\
\text { action of a novel relational } \\
\text { product, growing out of the } \\
\text { uniqueness of the individual } \\
\text { on the one hand, and the } \\
\text { materials, events, people, or } \\
\text { circumstances of his life on } \\
\text { the other." (p. 250). }\end{array}$ \\
\hline Rhodes & 1961 & $\begin{array}{l}\text { ". . is a noun naming the } \\
\text { phenomenon in which a } \\
\text { person communicates a new } \\
\text { concept (which is the } \\
\text { product). Mental activity (or }\end{array}$ \\
\hline
\end{tabular}




\begin{tabular}{|c|c|c|}
\hline & & $\begin{array}{l}\text { mental process) is implicit in } \\
\text { the definition, and of course } \\
\text { no one could conceive of a } \\
\text { person living or operating in } \\
\text { a vacuum, so the term press } \\
\text { is also implicit." (p. 305). }\end{array}$ \\
\hline Mednick & 1962 & $\begin{array}{l}\text { "... the forming of } \\
\text { associative elements into } \\
\text { new combinations which } \\
\text { either meet specified } \\
\text { requirements or are in some } \\
\text { way useful. The more } \\
\text { mutually remote the elements } \\
\text { of the new combination, the } \\
\text { more creative the process or } \\
\text { solution." (p. 221). }\end{array}$ \\
\hline Bruner & 1962 & $\begin{array}{l}\text { "... an act that produces } \\
\text { effective surprise." (p. 18). }\end{array}$ \\
\hline Koestler & 1964 & $\begin{array}{l}\text { "The creative act is not an act } \\
\text { of creation in the sense of the } \\
\text { Old Testament. It does not } \\
\text { create something out of } \\
\text { nothing: it uncovers, selects, } \\
\text { re-shuffles, combines and } \\
\text { synthesizes already existing } \\
\text { facts, ideas, faculties and } \\
\text { skills." (p. 120). }\end{array}$ \\
\hline Torrance & 1966 & $\begin{array}{l}\text { ". . a process of becoming } \\
\text { sensitive to problems, } \\
\text { deficiencies, gaps in } \\
\text { knowledge, missing } \\
\text { elements, disharmonies, and } \\
\text { so on; identifying the } \\
\text { difficult; searching for } \\
\text { solutions, making guesses or } \\
\text { formulating hypotheses about } \\
\text { the deficiencies, testing and } \\
\text { retesting these hypotheses } \\
\text { and possibly modifying and } \\
\text { retesting them, and finally } \\
\text { communicating the results." } \\
\text { (p. 8). }\end{array}$ \\
\hline May & 1975 & $\begin{array}{l}\text { "... the process of bringing } \\
\text { something new into being." } \\
\text { (p. 39). }\end{array}$ \\
\hline Welsch & 1980 & $\begin{array}{l}\text { "... the process of } \\
\text { generating unique products } \\
\text { by transformation of existing } \\
\text { products. These products, } \\
\text { tangible and intangible, must }\end{array}$ \\
\hline
\end{tabular}




\begin{tabular}{|c|c|c|}
\hline & & $\begin{array}{l}\text { be unique only to the creator, } \\
\text { and must meet the criteria of } \\
\text { purpose and value } \\
\text { established by the creator." } \\
\text { (p. 97). }\end{array}$ \\
\hline Amabile & 1983 & $\begin{array}{l}\text { ". . creativity can be } \\
\text { regarded as the quality of } \\
\text { products or responses judged } \\
\text { to be creative by appropriate } \\
\text { observers, and it can also be } \\
\text { regarded as the process by } \\
\text { which something so judged is } \\
\text { produced." (p. 31). }\end{array}$ \\
\hline Mumford \& Gustafson & 1988 & $\begin{array}{l}\text { ". . creativity appears to be } \\
\text { best conceptualized as a } \\
\text { Gustafson syndrome } \\
\text { involving a number of } \\
\text { elements: (a) the processes } \\
\text { underlying the individual's } \\
\text { capacity to generate new } \\
\text { ideas or understandings, (b) } \\
\text { the characteristics of the } \\
\text { individual facilitating process } \\
\text { operation, (c) the } \\
\text { characteristics of the } \\
\text { individual facilitating the } \\
\text { translation of these ideas into } \\
\text { action, (d) the attributes of } \\
\text { the situation conditioning the } \\
\text { individual's willingness to } \\
\text { engage in creative behavior, } \\
\text { and (e) the attributes of the } \\
\text { situation influencing } \\
\text { evaluation of the individual's } \\
\text { productive efforts." (p. 28). }\end{array}$ \\
\hline Vernon & 1989 & $\begin{array}{l}\text { ". . a person's capacity to } \\
\text { produce new or original } \\
\text { ideas, insights, } \\
\text { restructurings, inventions, or } \\
\text { artistic objects, which are } \\
\text { accepted by experts as being } \\
\text { of scientific, aesthetic, social } \\
\text { or technological value." (p. } \\
\text { 94). }\end{array}$ \\
\hline Boone \& Hollingsworth & Boone \& 1990 & $\begin{array}{l}\text { ". . any form of action that } \\
\text { leads to results that are } \\
\text { Hollingsworth novel, useful, } \\
\text { and predictable." (p. 3). }\end{array}$ \\
\hline Ochse & 1990 & $\begin{array}{c}\text { "... creativity involves } \\
\text { bringing something into }\end{array}$ \\
\hline
\end{tabular}




\begin{tabular}{|c|c|c|}
\hline & & $\begin{array}{l}\text { being that is original (new, } \\
\text { unusual, novel, unexpected) } \\
\text { and also valuable (useful, } \\
\text { good, adaptive, } \\
\text { appropriate)." (p. 2). }\end{array}$ \\
\hline $\begin{array}{l}\text { Mumford, Mobley, Reiter- } \\
\text { Palmon, Uhlman, \& Doares }\end{array}$ & 1991 & $\begin{array}{c}\text { "... does not represent a } \\
\text { unitary psychological } \\
\text { attribute, but rather an } \\
\text { outcome of a dynamic } \\
\text { interplay of certain } \\
\text { individual and situational } \\
\text { variables." (p. 91). }\end{array}$ \\
\hline Csikszentmihalyi & 1996 & $\begin{array}{l}\text { Csikszentmihalyi } 1996 \text { "... } \\
\text { any act, idea or product that } \\
\text { changes an existing domain, } \\
\text { or that transforms an existing } \\
\text { domain into a new one." (p. } \\
\text { 28). }\end{array}$ \\
\hline Herrmann & 1996 & $\begin{array}{l}\text { "Among other things, it is an } \\
\text { ability to challenge } \\
\text { assumptions, recognize } \\
\text { patterns, see in new ways, } \\
\text { make connections, take risks, } \\
\text { and seize upon a chance." (p. } \\
\text { 245). }\end{array}$ \\
\hline Naccce & 1999 & $\begin{array}{l}\text { "... an imaginative activity } \\
\text { fashioned so as to produce } \\
\text { outcomes that are original } \\
\text { and of value." (p. 29). }\end{array}$ \\
\hline Parkhurst & 1999 & $\begin{array}{l}\text { ". . is the ability or quality } \\
\text { displayed when solving } \\
\text { unsolved problems, when } \\
\text { developing novel solutions to } \\
\text { problems others have solved } \\
\text { differently, or when } \\
\text { developing original and } \\
\text { novel (at least to the } \\
\text { originator) products." (p. 18). }\end{array}$ \\
\hline Candy \& Edmonds & 1999 & $\begin{array}{l}\text { "... a set of activities that } \\
\text { give rise to an outcome or } \\
\text { product that is recognized to } \\
\text { be innovative as judged by } \\
\text { an external standard." (p. 4). }\end{array}$ \\
\hline Seltzer \& Bentley & 1999 & $\begin{array}{l}\text { "... is not an individual } \\
\text { characteristic or innate talent. } \\
\text { Creativity is the application } \\
\text { of knowledge and skills in } \\
\text { new ways to achieve a } \\
\text { valued goal." (p. viii). }\end{array}$ \\
\hline
\end{tabular}




\begin{tabular}{|c|c|c|}
\hline $\begin{array}{c}\text { Eisenberger, Haskins \& } \\
\text { Gambleton }\end{array}$ & 1999 & $\begin{array}{l}\text { "... involves the generation } \\
\text { of novel behavior that meets } \\
\text { a standard of quality or } \\
\text { utility." (p. 308). }\end{array}$ \\
\hline Sternberg \& Lubart & 1999 & $\begin{array}{l}\text { "... the ability to produce } \\
\text { work that is both novel (i.e. } \\
\text { original, unexpected) and } \\
\text { appropriate (i.e. useful, } \\
\text { adaptive concerning task } \\
\text { constraints)." (p. 3). }\end{array}$ \\
\hline Corsini & 1999 & $\begin{array}{l}\text { "Ability to apply original } \\
\text { ideas to the solution of } \\
\text { problems; the development } \\
\text { of theories, techniques or } \\
\text { devices; or the production of } \\
\text { novel forms of art, literature, } \\
\text { philosophy or science." (p. } \\
\text { 234). }\end{array}$ \\
\hline Csikszentmihalyi & 1999 & $\begin{array}{l}\text { "... a phenomenon that is } \\
\text { constructed through an } \\
\text { interaction between } \\
\text { producers and audience. } \\
\text { Creativity is not the product } \\
\text { of single individuals, but of } \\
\text { social systems making } \\
\text { judgments about individuals' } \\
\text { products." (p. 314). }\end{array}$ \\
\hline Aleinikov & 1999 & $\begin{array}{l}\text { "... the ability or the } \\
\text { process of producing } \\
\text { something new and useful." } \\
\text { (p. 840). }\end{array}$ \\
\hline Cropley \& Urban & 2000 & $\begin{array}{l}\text { "... the production of } \\
\text { relevant and effective novel } \\
\text { ideas." (p. 486). }\end{array}$ \\
\hline Boden & 2001 & $\begin{array}{l}\text { ". . is the ability to come up } \\
\text { with new ideas that are } \\
\text { surprising yet intelligible, } \\
\text { and also valuable in some } \\
\text { way". (p. 95). }\end{array}$ \\
\hline Van Hook \& Tegano & 2002 & $\begin{array}{l}\text { ". . the interpersonal and } \\
\text { intrapersonal process by } \\
\text { means of which original, } \\
\text { high quality, and genuinely } \\
\text { significant products are } \\
\text { developed." (p. } 3 \text { ). }\end{array}$ \\
\hline Feist \& Barron & 2003 & $\begin{array}{l}\text { "... is a specific capacity to } \\
\text { not only solve problems but } \\
\text { to solve them originally and } \\
\text { adaptively." (p. 63). }\end{array}$ \\
\hline
\end{tabular}




\begin{tabular}{|c|c|c|}
\hline Carayiannis \& Gonzalez & 2003 & $\begin{array}{l}\text { ". . the ability to perceive } \\
\text { new connections among } \\
\text { objects and concepts - in } \\
\text { effect, reordering reality by } \\
\text { using a novel framework for } \\
\text { organizing perceptions." (p. } \\
\text { 588). }\end{array}$ \\
\hline Mumford & 2003 & $\begin{array}{l}\text { "... involves the production } \\
\text { of novel, useful products." } \\
\text { (p. 110). }\end{array}$ \\
\hline Ward \& Saunders & 2003 & $\begin{array}{l}\text { "... is the result of the } \\
\text { convergence of basic } \\
\text { cognitive processes, core } \\
\text { domain knowledge, and } \\
\text { environmental, personal, and } \\
\text { motivational factors which } \\
\text { allow an individual to } \\
\text { produce an object or } \\
\text { behavior that is considered } \\
\text { both novel and appropriate in } \\
\text { a particular context." (p. } \\
\text { 862). }\end{array}$ \\
\hline Plucker, Beghetto \& Dow & 2004 & $\begin{array}{l}\text { ". . the interaction among } \\
\text { aptitude, process, and } \\
\text { environment by which an } \\
\text { individual or group produces } \\
\text { a perceptible product that is } \\
\text { both novel and useful as } \\
\text { defined within a social } \\
\text { context." (p. 90). }\end{array}$ \\
\hline Boden & 2004 & $\begin{array}{l}\text { "... the ability to come up } \\
\text { with ideas or artefacts that } \\
\text { are new, surprising and } \\
\text { valuable." (p. 1). }\end{array}$ \\
\hline Pope & 2005 & $\begin{array}{l}" . . \text { is extra/ordinary, } \\
\text { original and fitting, full- } \\
\text { filling, in(ter)ventive, } \\
\text { cooperative, un/conscious, } \\
\text { fe<>male, re . . creation." } \\
\text { (p. 52). }\end{array}$ \\
\hline Sawyer & 2006 & $\begin{array}{l}\text { ". . the emergence of } \\
\text { something novel and } \\
\text { appropriate, from a person, a } \\
\text { group, or a society." (p. 33). }\end{array}$ \\
\hline Runco & 2007 & $\begin{array}{c}\text { "... a reflection of } \\
\text { cognition, meta-cognition, } \\
\text { attitude, motivation, affect, } \\
\text { disposition, and } \\
\text { temperament." (p. 320). }\end{array}$ \\
\hline
\end{tabular}




\begin{tabular}{|c|c|c|}
\hline Barnes \& Shirley & 2007 & $\begin{array}{l}\text { ". . the act of putting two or } \\
\text { more ideas, materials or } \\
\text { activities together in what } \\
\text { feels (to the creators) like an } \\
\text { original, surprising and } \\
\text { valued way." (p. 164). }\end{array}$ \\
\hline Ferrari, Cachia \& Punie & 2009 & $\begin{array}{l}\text { ". . is skill for everyone; } \\
\text { ability to make new } \\
\text { connections; capacity to } \\
\text { generate new ideas; } \\
\text { divergent thinking; ability to } \\
\text { get out of the rails; capacity } \\
\text { to produce original and } \\
\text { valuable outcomes. (p. 14). }\end{array}$ \\
\hline $\begin{array}{l}\text { Kampylis, Berki \& } \\
\text { Saariluoma }\end{array}$ & 2009 & $\begin{array}{l}\text { "... the activity (both } \\
\text { mental and physical) that } \\
\text { occurs in a specific time- } \\
\text { space, social and cultural } \\
\text { framework and leads to } \\
\text { tangible or tangible outcomes } \\
\text { that are original, useful, } \\
\text { ethical and desirable, at least } \\
\text { to the creator(s)". (p. 18). }\end{array}$ \\
\hline
\end{tabular}

According to the authors in Table 1 in this list of definitions some concepts intersect. Namely those in the specialty literature are usually referred to as the four Ps of creativity (Richards, 1999): Person, Process, Pressure and Product. Thus, it can be considered that some of the authors agree, even partially, in their definitions. The common concepts are as follows:

1. Creativity is a key skill of individuals.

2. Creativity assumes an intentional activity or process.

3. The creative process occurs in a specific context or environment.

4. The creative process originates a product, tangible or intangible. The creative product must be new, original, unconventional, and appropriate, useful. At least from the perspective of the creative person.

Therefore, these characteristics of human criatividade apparently repeat themselves, according to the various experts. Creativity exists in people and happens by intention in a specific environment necessarily giving rise to a result. This result was certainly intended. This could perhaps be concluded that creativity happens out of necessity.

\section{Animal creativity}

Kaufman A.B., Butt A.B., Colbert-White E.N. \& Kaufman J.C. (2011) establish as the premise of their work around the neurobiology of animal creativity, the definition of creativity according to humans from Plucker \& Beghetto, (2004):

Creativity is the interaction among aptitude, process, and environment by which an individual or group produces a perceptible product that is both novel and useful as defined within a social context. 
In the same text and referring to animals, they ensure that "the whole theory of creativity in humans is applied point by point to animal creativity (...) eliminating the parts that do not apply."

Kaufman J. \& Kaufman A. (2016) point out that studies usually distinguish between creative capacity in animals as opposed to creative potential in humans. They stresse out that the difference may seem like one of semantics, however, exploring why studies of human creativity tend to focus on the concept of "potential" and why animal creativity tends to emphasize "ability" sheds light on how both concepts can work together to give an insight into how ability and potential can become "skill". In practice the dexterity, intelligence, and subtlety of realizing something new. Referring to the capacity for creativity they define it in the animal as "an important component of nonhuman animal research". It says that the term usually refers to a functioning neural system and the ability to create and use energy, genes that encode for the right proteins and motor skills. It emphasizes that natural selection favors creatures that do "enough" in obtaining resources, but without wasting them. In this way creativity, They conclude, can be seen as a tool to solve problems and find a better path to survival. So we also have creativity as something inherent of the animal, which happens in a context or environment, with an intention to produce a result that in this case would facilitate survival, using fewer resources. Kaufman A.B., Butt A.B., Colbert-White E.N. \& Kaufman J.C (2011) give the example of a Japanese monkey nicknamed "Imo" who learned to wash the potatoes, instead of cleaning them, to remove the sand that soiled them, or throw rice with mixed sand in a watering hole, to sink this and collect the first. The other neighboring monkeys, by imitation, adopted Imo's creative behavior. The authors conclude that it is obviously impossible to determine whether Imo's peers saw her as creative, but it would be reasonable to believe that they recognized the usefulness of their new behavior. The authors go further: saying that this recognition in themselves could be classified as an act of "lower-level creativity" because observation learning seems to depend critically on the cerebellum.

In addition to this example of Imo we know of others, such as parrots that know how to count, understand the concepts of equal or different, acquire language without direct training; In Nathional Geographic. (Ark Photo. Chimpanzee. 2015) chimpanzees that use basic tools such as shacks to catch ants; From Lindblad Expeditions (National Geographic. 2018) orcas that develop hunting and predation techniques, using fluid dynamics to hunt seals, or also from Nathional Geographic (How orcas hunt great whites fascinates biologists. 2020) tonic immobility to hunt sharks. These observations reinforce that creativity can be a biological phenomenon transversal to many species. If, as Kaufman A.B., Butt A.B., Colbert-White E.N. \& Kaufman J.C (2011) state, observation learning seems to depend critically on the cerebellum and this is precisely the organ that coordinates the body of the living being in the interaction with the environment, could creativity not be precisely a tool to intervene in this environment and thus provide a more effective and efficient survival in it? All living things have survival as their first existential priority. Even predators limit their hunts when they realize that prey can retaliate and thus question their survival. For example a lion can hunt juvenile or sick buffalo, but give up hunting a healthy adult buffalo, because it can invest against its hunter hurting it. Survival is the main existential anxiety of any living, animal or plant, only surpassed by one another. There is a greater existential anxiety that 
even overcomes the need for survival. This force is common to animals but also to humans. It's anxiety that leads prey to turn on predators, starving to give up food, victims turning against tyrants, fear to face the night, the cold, the fire. The only situation in which most living beings may give up their lives for another, give up their survival to ensure the survival of another being is when that other life is that of their offspring, of their children. The mother-child bonding (Gleitman, Fridlund \& Reisberg, 2014) is a matter of personal survival. For the mother, the main biological function remains that survival, but genetic and not personal. Once your offspring survive and reproduces, your genes, they will not disappear. We can perhaps conclude that the two greatest anxieties of any living being are thus the continuity of the species and the survival, in this order. This will eventually be a natural condition because it is common to virtually all living beings.

Evolutionary changes in animals, explained by Darwin (1872), are considered evolutionary successes when the fittest and most adaptable transmits their genetic burden to future generations. Darwin concluded this even in the evolution of species (Darwin, 1872). The animal manages to leave offspring in the right measure that manages to win in the fight for survival. In fact, most organisms do not live long enough to reproduce. Most tadpoles are consumed by predators and do not reach frogs, for example. Most of the seeds of a tree will not germinate in the plant. But there are certain characteristics that make them fitter. For example, the horse that runs faster will be the one that will best escape its predators. This does not mean that it reproduces or survives but increases these probabilities. Because they are the fittest who survive and reproduce. This also does not mean that in one species evolved from another the descendants are better than the ancestors. This is because the world is constantly changing. The drift of the continents, the formation of mountain ranges and their disappearance, lakes and rivers that appear and disappear, the climate that cyclically variates. These changes ensure that the species that best adapt are the ones that will be more likely to survive and reproduce, because they will be better suited to the environment at every moment.

\section{Neurological clues}

The way creativity seems to arise, usually spontaneous and without us consciously causing it is described by Andreasen N.C. (2011). Creative episodes arise in individuals when they do not seem to be thinking about the problem that requires creativity. This process is also described in some literature (Gleitman, Fridlung \& Reisberg, 2014a) as unconscious incubation. Andreasen tried to map the human brain in situations of rest or mental relaxation of the creative individual. The neuroscientist considers that the ability to originate new ideas, concepts, inventions, and objects of art is perhaps the most important attribute of the human brain. The studies, neuro imaging that carried out, of the brain during the PERIOD REST(random episodic silent thought), also referred to as the default state ) suggest that the association cortices are the main active areas during this state and the brain at that time is a system in spontaneous self-organizing action. That is, it appears to be at rest, but in reality it is in intense activity. Andreasen states that we are faced with the conclusion that creative thinking emerges from the subconscious rather than from the conscious process. 
In her observation creativity is not directly proportional to the value of IQ rather is a more "primordial" process. And above all, a process that occurs when our conscious is in apparent relaxation or rest, without our intervention. So, this describes a phenomenon that is somewhat involuntary. According to her conclusions the creative process is characterized by flashes of discernment that arise from subconscious reservoirs of the mind and brain. Neuroimaging studies that have carried out indicate that these reservoirs reside in association cortices. Thus, she concludes, during the creative process, the brain functions as a self-organized, autonomous system. The subconscious manner in which the phenomenon occurs suggests that there will be some kind of biological mechanism to lead the process. Once again creativity - driven by the will referred by Sternberg or other authors - and their components of the conscious, are called into question. Not because they do not participate in this, but because the evidences are indicating that there are probably others upstream causes and those are becoming more important in the process.

Sanders (2015) describes a surprising revelation. The cerebellum, which receives stimuli from the environment and reacts accordingly, being the original and primordial processing organ of the primate that gave rise to us, commands the instinct reactions of the body in the environment that surrounds it. The brain, which increasing in volume with human evolution subsequently involved it, is usually associated with more complex reasoning and abstraction. Because according to Sanders, the cerebellum may also be at the base of the creative process. This article describes as Saggar et al.(2015) conduct an experience at Stanford University where a sample of 30 participants, invited to draw verbs (levitate, exhale, whisper), were subjected to brain scans. The conclusion was: the more creative the drawing was, the greater the activity in the cerebellum. That is: creativity apparently arises from the cerebellum, such as learning by imitation, and so it will be perhaps a phenomenon as primitive as this organ, which dates back to our primate state.

\section{Conclusion}

It could make perfect sense to establish a relationship between creativity, subconscious and cerebellum. Especially if we consider that existing in animals other than humans, creativity is not just our characteristic. Manifesting itself apparently in the same way. Existing as a tool, which in fact facilitated the survival and continuity of the species, it was apparently precisely thanks to it that the fragile primate gradually became the sapiens and thus conquered the environment - despite the numerous dangers and predators - becoming at the apex of the predatory pyramid. Being these reflections correct, we could suggest a new definition for the phenomenon: creativity may be the biological mechanism of intervention in the environment, by some species, with the use of innovative solutions, to ensure the survival and continuity with the best efficiency of available means used. So perhaps we could say that creativity is the most extraordinary tool we have ever had to intervene in the environment. A truly powerful biological weapon. 
ALEINIKOV, A. G. (1999). Humane creativity. In M. A. Runco \& S. R. Pritzker (Eds.), Encyclopedia of creativity (Vol. 1, pp. 847-844). San Diego, CA: Academic Press.

AMABILE, T.M. (1983). The social psychology of creativity. New York: Springer-

Verlag.

Andreasen N. C., (2011), A Journey into Chaos: Creativity and the Unconscious. In: Brain, Mind and Consciousness: An International, Interdisciplinary Perspective (A.R. Singh and S.A. Singh eds.), MSM, 9(1), p 42-53..

BARNES, J., \& SHIRLEY, I. (2007). Strangely familiar: cross-curricular and creative thinking in teacher education. Improving Schools 10(2), 162-179.

BODEN, M. (2001). Creativity and knowledge. In A. Craft, B. Jeffrey \& M. Leibling (Eds.), Creativity in education (pp. 95-102). London: Continuum.

BODEN, M. A. (2004). The creative mind: myths and mechanisms (2nd ed.). London, London, London, New York: Routledge.

BOONE, L. W., \& HOLLINGSWORTH, A. T. (1990). Creative thinking in business organizations. Review of Business, 12(2), 3-13.

BRUNER, J. S. (1962). The conditions of creativity. In H. E. Gruber, G. Terrell \& M. Wertheimer (Eds.), Contemporary approaches to creative thinking: a symposium held at the University of Colorado (pp. 1-30). New York: Atherton Press.

Cabeça, Paulo, et al. 2020. A criatividade como processo do consciente e subconsciente na Arte. A Barrística como caso de estudo. Antologia de Ensaios LABORATORIO

COLABORATIVO: Dinâmicas Urbanas, Património, Artes. VI Seminário de Investigação, Ensino e Difusão. Publisher: DINÂMIA’CET-ISCTE. Pp. 295. http://hdl.handle.net/10071/20764

Cabeça, P.T. (2021). The Venus of our anxiety. The first art was visceral. Academia Letters, Article 454. https://doi.org/10.20935/AL454.

CANDY, L., \& EDMONDS, E. (1999). Introducing creativity to cognition. Proceedings of the 3rd conference on Creativity \& Cognition, (pp. 3-6). New York: ACM Press CARAYIANNIS, E., \& GONZALEZ, E. (2003).

Creativity+Innovation=Competitiveness? When, how, and why. In L. V. Shavinina (Ed.), The international handbook on innovation (1st ed., pp. 587-604). Amsterdam; Boston: Elsevier Science.

Cerebellum. In Infopédia. Consulted on March 26, 2020. Available in https://www.infopedia.pt/dicionarios/lingua-portuguesa/cerebelo

CORSINI, R. J. (1999). The dictionary of psychology. New York: Brunner-Rutledge. CREATIVITY. (2009). In Merriam-Webster Online Dictionary. Retrieved January 27, 2010, from http:// www.merriam-webster.com/dictionary/creativity.

CROPLEY, A. J., \& URBAN, K. K. (2000). Programs and strategies for nurturing creativity. In K. A. Heller, F. J. Mönks, R. Subotnik \& R. J. Sternberg (Eds.), International Handbook of Giftedness and Talent (pp. 481-494). Oxford: Elsevier. CSIKSZENTMIHALYI, M. (1996). Creativity: flow and the psychology of discovery and invention (1st ed.). New York: Harper Collins Publishers. 
CSIKSZENTMIHALYI, M. (1999). Implications of a systems perspective for the study of creativity. In R. J. Sternberg (Ed.), Handbook of creativity (pp. 313-338). Cambridge, U.K.; New York: Cambridge University Press.

Darwin, 1872a quoted in Gleitman, H.Fridlund A.,Reisberg D. 2014. Psychology. Caloust Foundatione Gulbenkian. 10th edition. P.P.547.

EISENBERGER, R., HASKINS, F., \& GAMBLETON, P. (1999). Promised reward and creativity: Effects of prior experience. Journal of Experimental Social Psychology, 35(3), 308-325.

FEIST, G. J., \& BARRON, F. X. (2003). Predicting creativity from early to late adulthood: Intellect, potential, and personality. Journal of Research in Personality 37(2), 62-88.

FERRARI, A., CACHIA, R., \& PUNIE, Y. (2009). Innovation and Creativity in Education and Training in the EU Member States: Fostering Creative Learning and Supporting Innovative Teaching — Literature review on Innovation and Creativity in E\&T in the EU Member States (ICEAC). Luxembourg: Office for Official Publications of the European Communities.

Gleitman, H., Fridlund A., Reisberg D. 2014. Psychology, psychology. Calouste Gulbenkian Foundation. 10th edition. pp.547.

Gleitman, H.,Fridlund A.,Reisberg D. 2014a. Psychology. Calouste Gulbenkian Foundation. 10th edition. pp.428

GUILFORD, J. P. (1950). Creativity. American Psychologist, 5, 444-454.

HERRMANN, N. (1996). The whole brain business book. New York: McGraw-Hill. Lindblad Expeditions-National Geographic. 2018. Wave Hunting: Prey Orcas on Seal. Antarctica Consulted on May 4, 2020. Available in https://www.youtube.com/watch?v=K161ZU0agbg

KAMPYLIS, P., BERKI, E., \& SAARILUOMA, P. (2009). In-service and prospective teachers' conceptions of creativity. Thinking Skills and Creativity, 4(1), 15-29.

Kampylis, Panagiotis \& Valtanen, Jury. (2010). Redefining Creativity - Analyzing

Definitions, Collocations, and Consequences. Journal of Creative Behavior. 44. 191214. 10.1002/j.2162-6057.2010.tb01333.x.

Kaufman A.B., Butt A.B., Colbert-White E.N. \& Kaufman J.C. Towards a neurobiological model of creativity in nonhuman animals. Journal of Comparative Psychology, 2011, vol. 125, pp. 255- 272

Kaufman J.C., Kaufman A.B. Capacity, potential, and ability: integrating different approaches to studying animal vs human creative processes. RUDN Journal of Psychology and Pedagogics. 2016. 4, 29-36. Consulted on 31 July 2020. Available in https://www.researchgate.net/publication/327564565_CAPACITY_POTENTIAL_AND _ABILITY_INTEGRATING_DIFFERENT_APPROACHES_TO_STUDYING_ANIM AL_VS_HUMAN_CREATIVE_PROCESSES

Kaufman J., Sternberg R., 2006. The international handbook of creativity. Cambridge. P.p. 6

KOESTLER, A. (1964). The act of creation. London: Hutchinson. 
MAY, R. (1975). The courage to create. New York: W. W. Norton.

MEDNICK, S.A. (1962). The associative basis of the creative process. Psychological Review, 69, 220-232.

MUMFORD, M. D. (2003). Where have we been, where are we going? Taking stock in creativity research. Creativity Research Journal, 15 (2 \& 3), 107-120.

MUMFORD, M. D., \& GUSTAFSON, S.B. (1988). Creativity syndrome: Integration, application, and innovation. Psychological Bulletin, 103(1), 27-43.

MUMFORD, M. D., MOBLEY, M. I., REITER-PALMON, R., UHLMAN, C. E., \& DOARES, L.M. (1991). Process analytic models of creative capacities. Creativity Research Journal, 4(2), 91 - 122.

NACCCE - National Advisory Committee on Creative and Cultural Education. All our futures: Creativity, culture and education. London: DSEE.

Nathional Geographic. How orcas hunt great whites fascinates biologists. 2020.

Retrieved 4 May 2020. Available in

https://video.nationalgeographic.com/video/animals-source/0000016b-f723-d5f3-a1fbf7ff 14210000

Nathional Geographic. Ark Photo. Chimpanzee. 2015. Retrieved May 4, 2020.

Available https://www.nationalgeographic.com/animals/mammals/c/chimpanzee/

NEBER, C. (1988). The dark side of creativity: Blocks, unfinished works and the urge to destroy. New York: Whitston Publishing Company.

OCHSE, R. (1990). Before the gates of excellence: the determinants of creative genius.

Cambridge, Cambridge, New York: Cambridge University Press.

PARKHURST, H.B. (1999). Confusion, lack of consensus, and the definition of creativity as a construct. Journal of Creative Behavior, 33(1), 1-21.

PIIRTO, J. (2004). Understanding creativity. Scottsdale, Ar.: Great Potential Press.

PLUCKER, J. A., BEGHETTO, R. A., \& DOW, G. T. (2004). Why isn't creativity more important to educational psychologists? Potentials, pitfalls, and future directions in creativity research. Psychologist Educational, 39(2), 83-96.

POPE, R. (2005). Creativity: history, theory and practice. London: Routledge.

Puryear J.Lamb Kristen. 2019. Defining Creativity: How Far Have We Come Since Plucker, Beghetto, and Dow?. https://doi.org/10.1080/10400419.2020.1821552

RHODES, M. (1961). An analysis of creativity. Phi Delta Kappan, 42(7), 305-310.

RICHARDS, R. (1999). Four Ps of creativity. In M. A. Runco \& S. R. Pritzker (Eds.), Encyclopedia of creativity (Vol. 1, pp. 733-742). San Diego, CA; London: Academic Press.

ROGERS, C. R. (1954). Toward a theory of creativity. ETC: A Review of General Semantics, 11(4), 250-258.

RUNCO, M. A. (2007). Creativity-Theories and themes: research, development, and practice. Amsterdam; Boston: Elsevier Academic Press.

Saggar, Manish \& Quintin, Eve-Marie \& Kienitz, Eliza \& Bott, Nicholas \& Sun, Zhaochun \& Hong, Wei-Chen \& Chien, Yin-Hsuan \& Liu, Ning \& Dougherty, Robert \& Royalty, Adam \& Hawthorne, Grace \& Reiss, Allan. (2015). Pictionary-based fMRI 
paradigm to study the neural correlates of spontaneous improvisation and figural creativity. Scientific reports. 5. 10894. 10.1038/srep10894.

Sanders, Laura. May 28, 2015. Cerebellum may be site of creative spark. Sciencenews. Consulted on March 26, 2020. Available in https://www.sciencenews.org/article/cerebellum-may-be-site-creative-spark SAWYER, R. K. (2000). Improvisation and the creative process: Dewey, Collingwood, and the aesthetics of spontaneity. The Journal of Aesthetics and Art Criticism, 58(2), 149-161.

SAWYER, R. K. (2006). Explaining creativity: the science of human innovation.

Oxford; New York: Oxford University Press.

SELTZER, K., \& BENTLEY, T. (1999). The creative age - Knowledge and skills for the new economy. London: Demos.

STARKO, A. J. (2005). Creativity in the classroom: schools of curious delight (3rd ed.). Mahwah, NJ: L. Erlbaum Associates. P.p.6

STEIN, M. (1953). Creativity and culture Journal of Psychology, 36, 311- 322.

STERNBERG, R. J., \& LUBART, T. (1999). The concept of creativity: Prospects and paradigms. In R. Sternberg (Ed.), Handbook of Creativity (pp. 3-15). Cambridge, U.K.: Cambridge University Press.

Sternberg, R. J., \& Lubart, T. I. (1992). Buy low and sell high: An investment approach to creativity. Current Directions in Psychological Science, 1(1), 1-5.

TORRANCE, E. P. (1966). Torrance test on creative thinking: Norms- Technical Manual Research Edition. Princeton NJ: Personnel Press.

VAN HOOK, C. W., \& TEGANO, D. W. (2002). The relationship between creativity and conformity among preschool children. Journal of Creative Behavior, 36(1), 1-16 VERNON, P. E. (1989). The nature-nurture problem in creativity. In J. A. Glover, R. R. Ronning \& C. R. Reynolds (Eds.), Handbook of Creativity: perspectives on individual differences (pp. 93-110). New York, NY: Plenum Press.

WARD, T., \& SAUNDERS, K. (2003). Creativity. In L. Nadel (Ed.), Encyclopedia of Cognitive Science. London: Natural Publishing Group.

WELSCH, P. K. (1980). The nurturance of creative behavior in educational environments: A comprehensive curriculum approach. Unpublished doctoral dissertation. University of Michigan, Michigan. 